\title{
When the Centre Turns to Suburbia Re-use of Ragusa: Sustainable Strategies to Revive the City Centre
}

\begin{abstract}
When heritage policies and benefits have gradually enabled the process of renovation of the most attractive historical centres, the densest and poorest of them, not being able to count on the rescue provided by tourism, are doomed to suffer from their loss of 'utilitas' The double historic centre of the Sicilian city of Ragusa could be a perfect case offering an opportunity to experiment with the innovative potential of this condition. Ragusa is currently a city with the highest ratio of the real estate surface per capita in Italy. If today Ragusa Ibla regained its vitality as a tourist and nightlife destination, Ragusa Superiore needs a new and extensive regeneration process to be launched, which requires comprehensive planning strategies to be adopted and strong economic subsidies to be secured - as the first step, by organising an architectural and urban planning workshop devoted entirely to the historic centre of Ragusa Superiore, a part of a cycle of International Designing Workshops 'Territories in Evolution" and drew on its years of experience. In any case and in each and every urban centre, basing on a general, common programme drawn up in advance, the objective of any designing workshop is to concentrate proactive skills of an international working group 'in situ'. The Re-use Ragusa workshop very quickly unleashed a number of ideas, the effects of which can be considered specific and realistic methods of reviving the historic Ragusa. Thanks to the work during the workshop "Re-use Ragusa: Sustainable Strategies to Revive the City Centre", the students and lectures who were lucky enough to experience the town on a daily basis: live and work here, recollecting their experience of only two weeks in the historic centre of Ragusa Superiore, demonstrated to themselves and to the town residents that positive thinking about an urban and architectural design may offer new perspectives which can creatively benefit from and enhance the already existing resources. The effects of this workshop are the fruit of successful, if unusual, cooperation between municipal authorities and administrators on the one hand and the university on the other, organising this wider highly professional international support.
\end{abstract}

Key words: loss of 'utilitas', Re-use Ragusa, methods of reviving the historic Ragusa

"L'architettura e un punto di vista che desideriamo condividere"

"Architecture is a point of view which we wish to share"

L. Mies van der Rohe

\section{Matters of a Fragile but Resilient Urban Landscape}

Since the post-war period, the phenomenon of the abandonment of city centres has been closely linked to urban growth; in a way it can be considered a footprint of its frantic rush. The beating heart of our densest cities soon turned into the most paradoxical and dramatic form of suburbia. For several decades the most concrete and emblematic representation of sociality and citizenship has been left to chase the illusion of a new model of a more comfortable yet secluded way of life, which eventually led to the sprawling of scattered and disjointed settlements. This widespread problem still affects many cities in Sicily and Southern Italy.

When heritage policies and benefits have gradually enabled the process of renovation of the most attractive historical centres, the densest and poorest of them, not being able to count on the rescue provided by tourism, are doomed to suffer from their loss of 'utilitas'. If the fragility of the former lies in their perfection and is therefore com- pensated by protection afforded by institutions, the fragility of the latter lies in the imperfection of their landscapes altered by the consequences of shortsighted plans, which, missing their morphological value, actually left them to the fringe of urban development. This imperfection and this major complexity require a new vision of urban development and offer a challenging opportunity to rethink how to reuse the city and to promote new experiences of inclusivity and urban sharing.

The double historic centre of the Sicilian city of Ragusa could be a perfect case offering an opportunity to experiment with the innovative potential of this condition. On the one hand, Ragusa Ibla, locked in a static image of its late baroque architecture, has become an ideal setting for tourism and leisure. On the other, Ragusa Superiore with its fragile and flawed landscape has still to find the perspectives for its regeneration.Its weak points (the density of the fabric, the seriality of building types, the lack of public spaces, the uncertainty of the borders), which today are perceived as limitations, can be the starting points for rethinking of its urban form from within. 


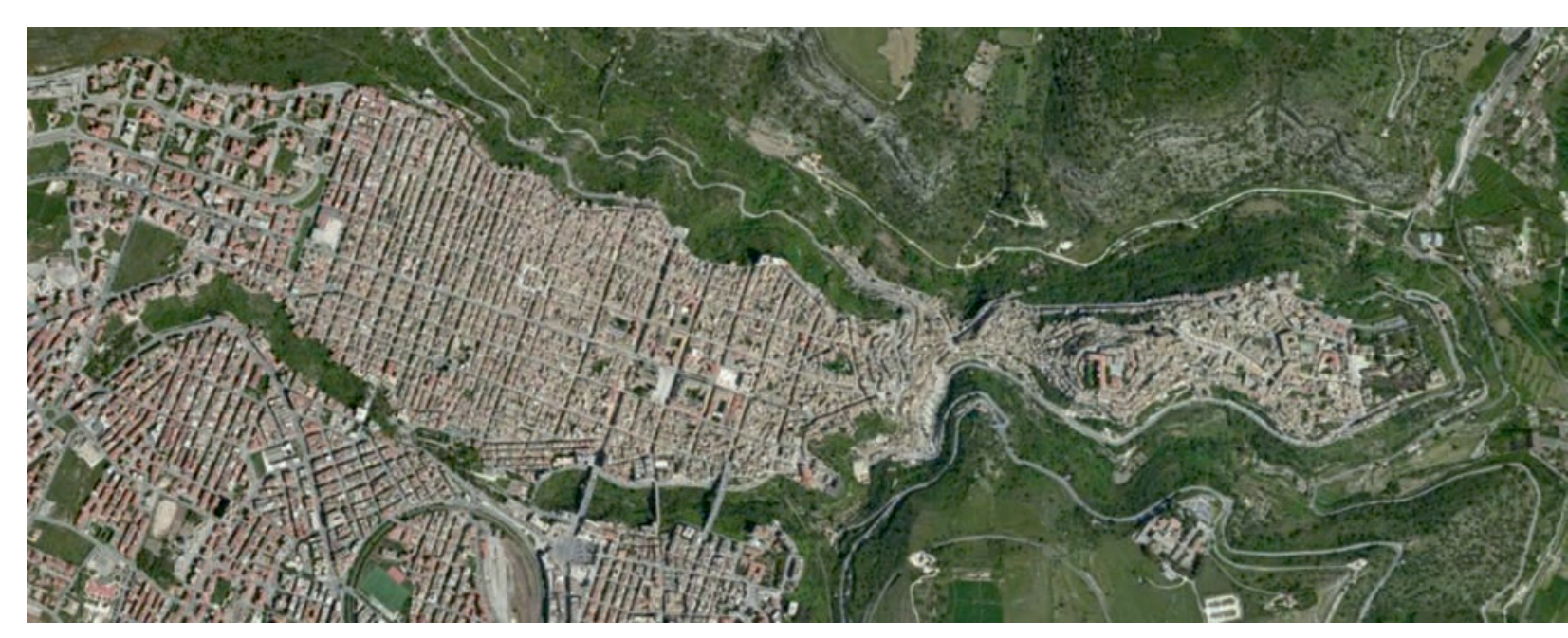

III. 1. Satellite's view of the current structure of Ragusa, Re-Use Ragusa, Territoti in Evoluzione; Strategie sostenibili per far rivivere il centro
storico, Ragusa, $16-28$ settembre 2014; post-workshoppublishing 2015

\section{The Sense of Context}

Ragusa, the capital of Sicilian Baroque, is a perfect location to host a 'laboratory of ideas' focused on architectural, urban, and environmental issues, due to the consistency of its architectural and monumental heritage, but also owing to the complexity of its urban structure, process. The selected theme for the first step concerns the regeneration of the historic centre of Ragusa Superiore, the 'new town' built on a higher plateau after the earthquake which destroyed the old city in 1693 . The historic centre, shaped on a compact gridiron plan, encompasses several late Baroque palaces.

The denser part of this fabric, composed of an extensive grid of small blocks, each consisting of tiny lots, has gradually proved inadequate to accommodate new housing needs, forcing residents to look elsewhere for more suitable conditions. A strict regulation imposed on the whole historic centre has strongly contributed to perpetuating this condition, by preventing the necessary
renewal process. The consequence has been a gradual renewal process. The consequence has been a gradual
depopulation of the old town, which led to a large urban depopulation of the
and social decay.

Ragusa is the main town of the southernmost province of Italy and one of the eight towns in South-Eastern Sicily, included in the UNESCO World Herlage List in 2002 for the inovat the un the Quar belonging to as well as social conflicts existing betwen the feuda aristocracy and the the town to be rebuilt as split into two parts. The nobitity chose to rebuld their new city on the ruins of the old one, gradually erecting on the medieval urban plan new Baroque architecture forming a peculiar architectural unity of Ragusa lbla, which culminates in the new church of St. George. The emerging agricultural middle class ('massari') chose instead to urbanise the Patro pla teau, the highest hill west of lbla, where they started to build a second independent core. The 'new town' was planned according to an orthogonal grid. The 'Mother Church', dedicated to St. John the Baptist, was erected just in its centre.

The building process of Ragusa Superiore proturies. The fabric consists of two different parts with different types of blocks and buildings: the eastern sector is arranged according to an approximately $90 \mathrm{~m} \times 90 \mathrm{~m}$ square grid; in its central area (between Via Roma, Via San Vito, Corso Italia, and Via Vittorio Veneto) remarkable baroque palaces and monuments are inserted.The western grid is fragmented and subjected to more intensive development: small blocks are parcelled into many lots, sometimes smaller than 20 square metres, with more recent and ordinary buildings within their perimeter.

The double slope of the ground, from west to east and from north to south, warps the final shape of the urban grid. On the borders of the plateau the fabric suddenly stops along curved edges overlooking the two valleys that surround the hill: the deep San Leonardo valley to the north, and the Santa Domenica valley to the south. The latter separates the historic centre of Ragusa Superiore from its further extension southwards, towards the frer the construction of the Capuchins bidged the end of the $19^{\text {th }}$ century

of facilities, squares, and pubgresult of introduce hierarchies and public spactans tried to somorphic grid in the different districts, but they were ignored. The first is the city plan drawn up by G. Migliorisi and approved in 1880, which provided for an adaptation of the grid to the needs of vehicular traffic by means of widening some streets and integrating new facilities (market, theatre), as ceeded from east to west over two and a half cen-

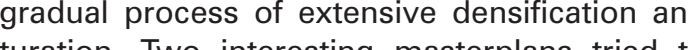

well as squares (Casino and Serra neighbourhoods), and public gardens (Borgo Cappuccini).

The second is the project drawn up by F. La Grassa and awarded at the competition for the new cily plan in 1928. Here the 'thinning' and street widening opertions planned for the city centre were integrated withi the general development of a new scale street network supporting the natural extension of the city southward and westward.

In the 1930s, after the opening of the new bridge ove the Santa Domenica valley on the axis of Via Roma and subsequent implementation of a new square surround ed by public buildings (Plazza Liberta), the southern district of the New Ragusa'was equipped with a new core ralway station. The new square was designed by a raionalist architect, Enesto B. La Padula well known as the EUR district of Rome.

After the World War Il the historic centre of Ragusa Superiore went through gradual saturation whenusa Supublic and private buildings were built along the borders of the valley (seats of the Provincial Administration and Civil Engineering). In 1960 the third bridge was constructed as an extension of San Vito Street.

The city plan approved in 1974 left the old town of Ra gusa Superiore out from the restricted category of 'historic centre', hence several buildings were demolished to house very imposing multi-story buildings, such as the INA insurance palace in front of St. John's Cathedral, the Bank of Sicily, the new Courthouse.Since that moment, gradual depopulation of the old town led to considerable decay of houses and businesses that were forming the socioeconomic fabric of the centre.

Symmetrically, extensive construction activitieswere rapidly carried out westward, giving rise to new housing districts with several apartment buildings and detache houses. Furthermore, on the coast a lot of summer houses started to be built in the satellite and seasonal tow of Marina di Ragusa, thus leading to another doubling of the city: Ragusa is currently a city with the highest ratio ofthe real estate surface per capita in Italy.

A more recent Masterplan of the City Centre, adopted to overcome the deregulations of the previous years, still

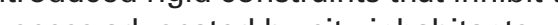
process advocated by city inhabitants.

\section{Workshop: Re-use Ragusa: Back to the Centre}

If today Ragusa Ibla regained its vitality as a tourist and nightlife destination, Ragusa Superiore needs a new and extensive regeneration process to be launched, which requires comprehensive planning strategies to be adopted and strong economic subsidies to be secured. This situation gave rise to an idea of the workshop - using a multidisciplinary approach - with the aim to test "on-site" strategies for urban renewal that could sugges integrated solutions to several issues: preservation of the architectural and urban character of the site, building and public space renovation, upgrading of the urban tissue to the current housing and traffic needs, creation of safety areas for both seismic and hydrogeological risks.
After a preliminary guided analysis of the urban context, participants carry out design experiments at different scales on sampla frame or along its borders built along the edges of the plateau. Specific methods of intervention were discussed within working groups, each headed by a tutor, which were accompanied by scheduled seminars, conferences, and panel discussions. Accepting the readiness of Ragusa municipality to initiate research activities in the city with great enthusiasm, we believed it was necessary to commence cooperation by organising an architectura and urban planning workshop devoted entirely to the historic centre of Ragusa Superiore, in particufor

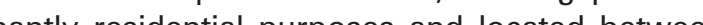
ria

In the very title of the workshop, "Re-use Ragusa: we tried to emphies to Revive the City Centre", of this initiative, aimed to develop a revitalisation strategy for the city centre basing on the reuse of covered and open spaces. The initiative was motivated by the willingness to restore the vitality of the historic centre, which - plagued by years of a slow process of depopulation - had declined leading to the current degradation of buildings and social decay.

The workshop in Ragusa was a part of a cycle and drew on its years of experience. International designing workshops entitled "Territories in Evolution" are a travelling space for meetings and work of architecture professors and students from universities and colleges of technology from all over the world, during which they directly address actual topics and issues associated with urban planning and architectural design in the atmosphere of confrontation and intensive and well-organised cooperation. Our previous experience associated with workshops (www.architecturelab.eu) had demonstrated the power of specific topics and of freedom when facing them.

In any case and in each and every urban centre, basing on a general, common programme drawn up in advance, the objective of any designing international working group 'in situ'.

Wencentrating work and research in a short period of time forces to seek a synthesis in which different experiences of workshop participants differexist and complement each other so as to achieve the required designing objective, optimat in specific conditions.

In Ragusa, the workshop participants, 40 students and Ph.D. candidates from different European universities, encouraged to adopt an interdisciplinary perspective and supervised by their professors and tutors, recruited predominantly from amongst young architects from the region, were contemplating the causes of the decadence of this part of 
the city. By means of specific tools of a very intensive (a) servation of the city and on a thorough and direct obdiverse voices. It was possible thanks to meeting representatives of different social groups and experts on social, economic, and cultural aspects of the city. But what contributed the most were strolls around the city districts, organised by Prof. Flaccavento, in search memories emerging from streets and alleys of Patro. The course of the workshop was also animated by a cycle of thematic conferences, during which speeches were delivered by the participating lecturers, city adin archicture and internation as inved expers presented their experiences on the ban po reve tions of cities in Europe and engaged in a dialogue with workshop participants, thus contributing to the designing process at each of its stages.

The Re-use Ragusa workshop very quickly unleashed a number of ideas, the effects of which can be considered specific and realistic methods of reviving the historic Ragus

Areas, Topics, Designs - New Perspectives

The urban results of the workshop presented herein consist of six different design proposals - one for each of the six parts of the analysed city sector. The area was divided along the axes of streets running transversely towards Via Roma, Garibaldi, Schinina, Gagini, and along the axis of the longitudinal Corso Italia. Areas not subjected to interventions were S. S.Giovanni, Ecce Homo, Fonti, and IV Novembre. Undoubtedly, the six area-related designs $p$ the quality of the place, and exclusively for the place for which they were planned.

The six final planimetric systems, re-arranged like a collage on the city map in the scale 1:500, create and revive a Ragusa analogous, but also alternative to

the existing city of fragments, the currently dire with harbingers of so to occur in the future. As it is pointed out in the final discussion, each group during their work o individual parts of the city imagined their part as a component of a whole, closing the entire sector as 'a complete city'. Each of the six 'pieces' contained well-grounded ideas and strategic indications, which influence the sector and the entire structure of the historic centre, even if they address a specific part within the sector.

(1) to present the adopted methodology and the results so Italia $M$. Schinina Similarly to the other five groups, it consisted of lecturers (Ado Donatllo Franchini Carlo Alberto Maggiore) a supervisor (arch. Davide Fusari), and students (Marta Johanovic Chenge Li Adriana Mancuso, Francesca Mirabella, Piotr Paradowski, Giulia Sangiani, Raul Valvasori).

The sector between Corso Italia and the streets of Via Gagini and M. Schinina consists of the most recent part of the fragmented urban tissue of Ragusa Superiore, which encompasses the entire western section of the historic centre. The isomorphic grid of the streets suddenly stops towards the south from the developed limit at the edge of the Di Santa Domenica valley. S. Salvatore street; on the other side, its irregular course is intersected in the middle with a short section of a diagonal street (the first section of Corso Vittorio Veneto), which reflects a former agricultural path and constitutes one of very few exceptions from the regime of the orthogonal development plan.

The need to rationalise the traffic flow emerged im mediately as a priority for the qualitative reform of the public space. Currently, this area struggles with considerable 'parasite traffic' directed along Via Ar-

III. 2. The existing condition of the urban structure of Ragusa-Superiore, Re-Use Ragusa, Territoti in Evoluzione; Strategie sostenibili per far III. 2. The existing condition of the urban structure of Ragusa-Superiore, Re-Use Ragusa
rivivere il centro storico, Ragusa, 16 -28 settembre 2014 ; post-workshoppublishing 201
III. 2 . The effect of the workshop: a collage of six concepts of wrban transformations

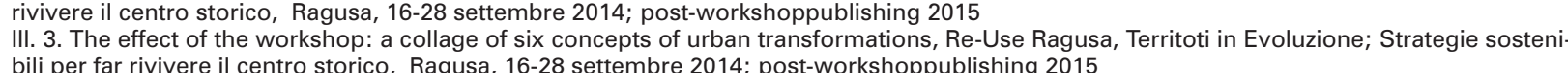
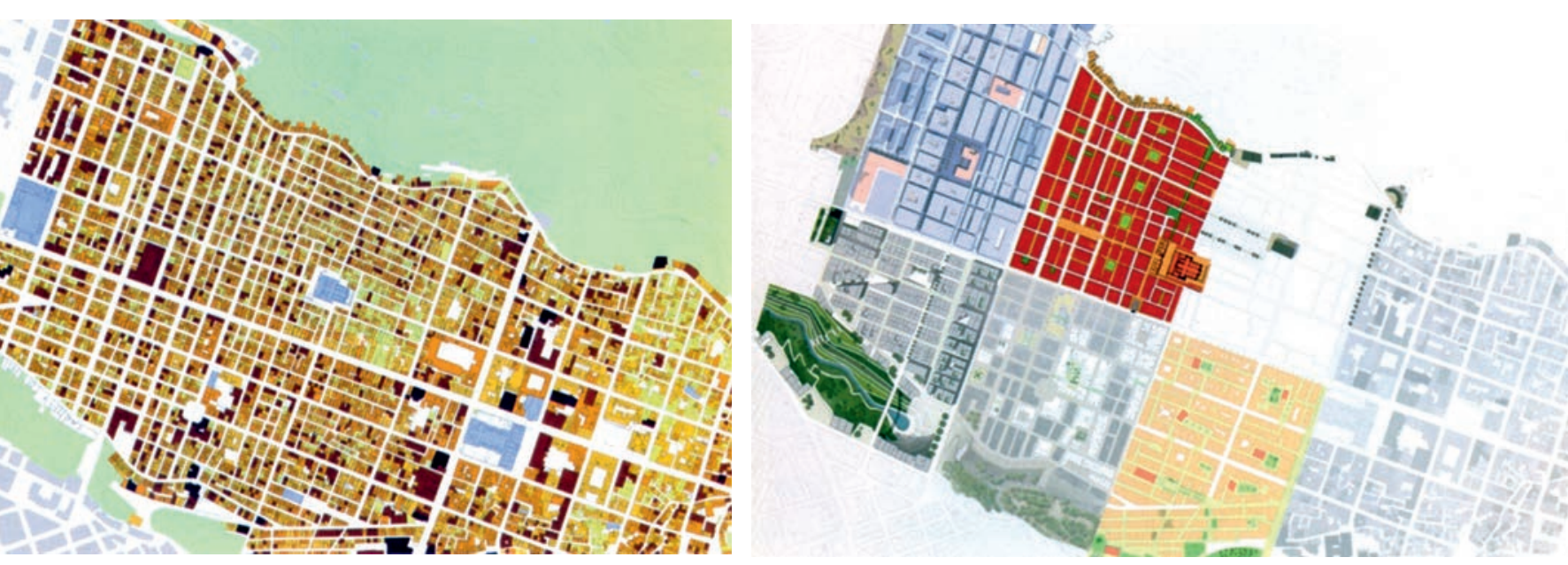

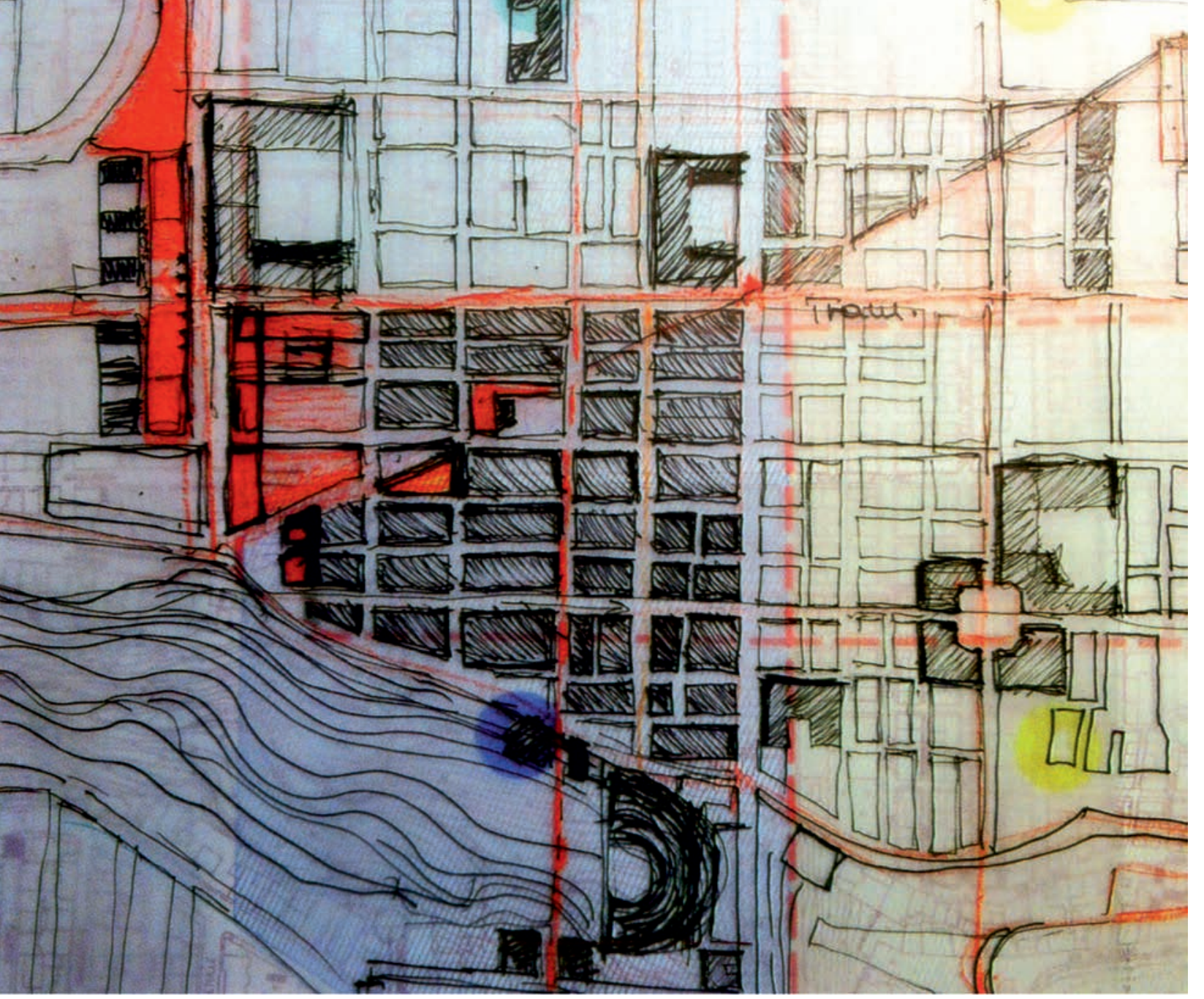

III. 4. A concept sketch of transformations of the upper urban structure, with th Diagonal intersection, by Ado Franchini, Re-Use Ragusa, Terri-
toti in Evoluzione; Strategie sostenibili per far rivivere il centro storico, Ragusa, $16-28$ settembre 2014; post-workshoppoblishing 2015

chimede, the rationalisation of which can considerably mprove cohesion within the district.

The topics tackled by the project can be shortly classified in five points:

order to reduce the local traffic and penetration along Corso Italia, a hypothesis relating to the parking structure was made. On the one hand it referred to a big car park possible to be implemented by making use of a slope and the difference of altitude between Via Gagini and Via Canova. Synergistically, the axis of Cor nished with a two-way tram line could help to service the the parking spaces at Matteotti Square and Via Gagin the parking spaces at Matteotti Square and Via Gagin The diagonal segment of Corso Vittorio Veneto was interpreted as a fragment initiating the concept of diagonal intersection of the square grid spanning from the valley to the valley - as far as the Belvedere rotund located at the northern end of Via Roma. Inner structures of the structure based on a triangular or trapezoidal plan, generated by different directions of passages, through liquidation of some minor covered areas were transformed into a system of squares - continued in other segments of the transformed sector - combined with each other and arranged on two different levels corresponding to the downslope that occurs here. They are associate with services for the neighbourhood and with com- mercial spaces. Likewise, irregular blocks at Via S. Salvatore can be partly reduced so as to allow the creation of a second system of small piazzas ove looking the S. Domenico valley.

Writit(he nanty pedestrian, with low-rise buildings - aniform cluster of houses with a specific identity. The axis, extended with a new footbridge over the valley, could provide other parts of the town with quick pedcestrian access along Via Archimede to the historic centre.

The blocks between Via Schinina and Via Scrofan were investigated in terms of the possibility of environmental requalification based on a micro-intervention - thinning. Highlighting theinner diagona street (Via La Masa), yet another exception from the regular urban tissue, small open neighbourhood spaces were created. The development typology was enriched with internal patios by means of minor interventions consisting in reducing the volume of buildings and transforming the number of buildings into the quality of residence.

The edge created on the limit of the S. Domenico quarry is characterised by an enormous volume of buildings of considerable height, erected predomi- 


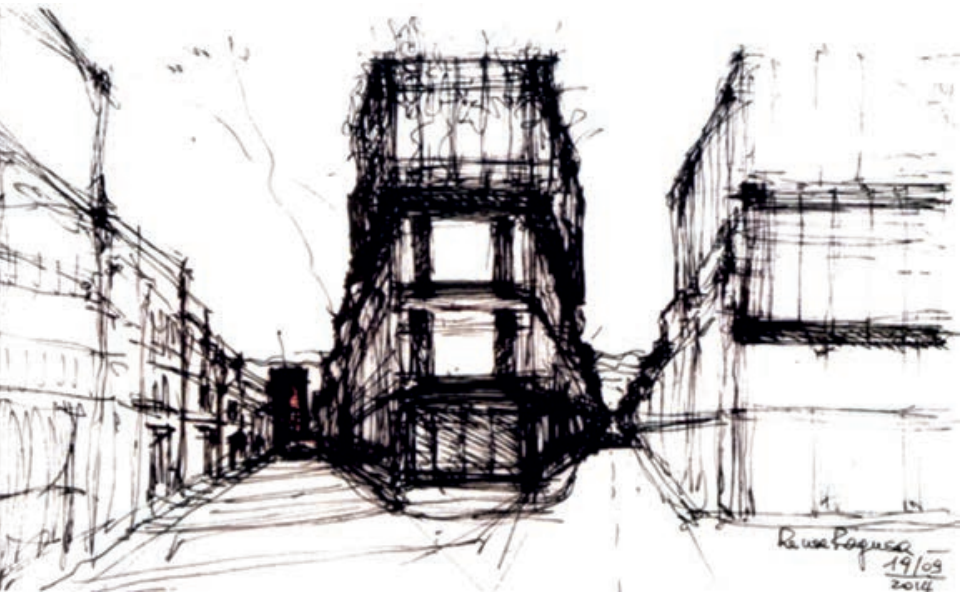

III. 5. A sketch of the starting point of the 'Diagonal', by Ado Franchin Re-Use Ragusa, Territoti in Evoluzione; Strategie sostenibili i per far
rivivere il centro storico, Ragusa, $16-28$ settembre 2014; post-works-
hoppeblishto

nantly on land exhibiting a high seismic risk. For this reason, 'a next-day map' was sketched, marking buildings which due to their structure are exposed to the highes risk of collapse in the event of an earthquake. Implementation of a controlled demolition programme in order to protect residents may correspond to the rebuilding of

the edge, and to be more precise to the opening of soc the creating of new open spaces, attractive for social life and promotion of new activities.

Post-Workshop Reflection: When Can the Centre Stop Transforming into the Suburbia

Ranks to the work during the workshop "Re-use Ragusa: Sustainable Strategies to Revive the City Centre, , the students and lectures who were lucky enough to experience the town on a daily basis: live and work here, recollecting their experience of only two weeks in the historic centre of Raguthe town residents that positive thinking and to urban and aichits thr posive think fes about an pectives which can crealively benefit from and enhance the already existing resources.

According to the experience of some of the Acuests, who have been active crears of archiguetural and urban revitalistions for decades and have wonderful achievements in this respect, such as the Autonomous Province of Bolzano or 'Ayuntamiento de Madrid, the cultural revolution which the revitalisation process always is, to greater or lesser extent, comes about by mean of comparisons, and therefore by skilful inspira-

III. 6. The design result obtained, Re-Use Ragusa, Territoti in Evoluzione; Strategie sostenibili per far rivivere il centro storico, Ragusa, 16-28
settembre 2014; post-workshoppublishing 2015
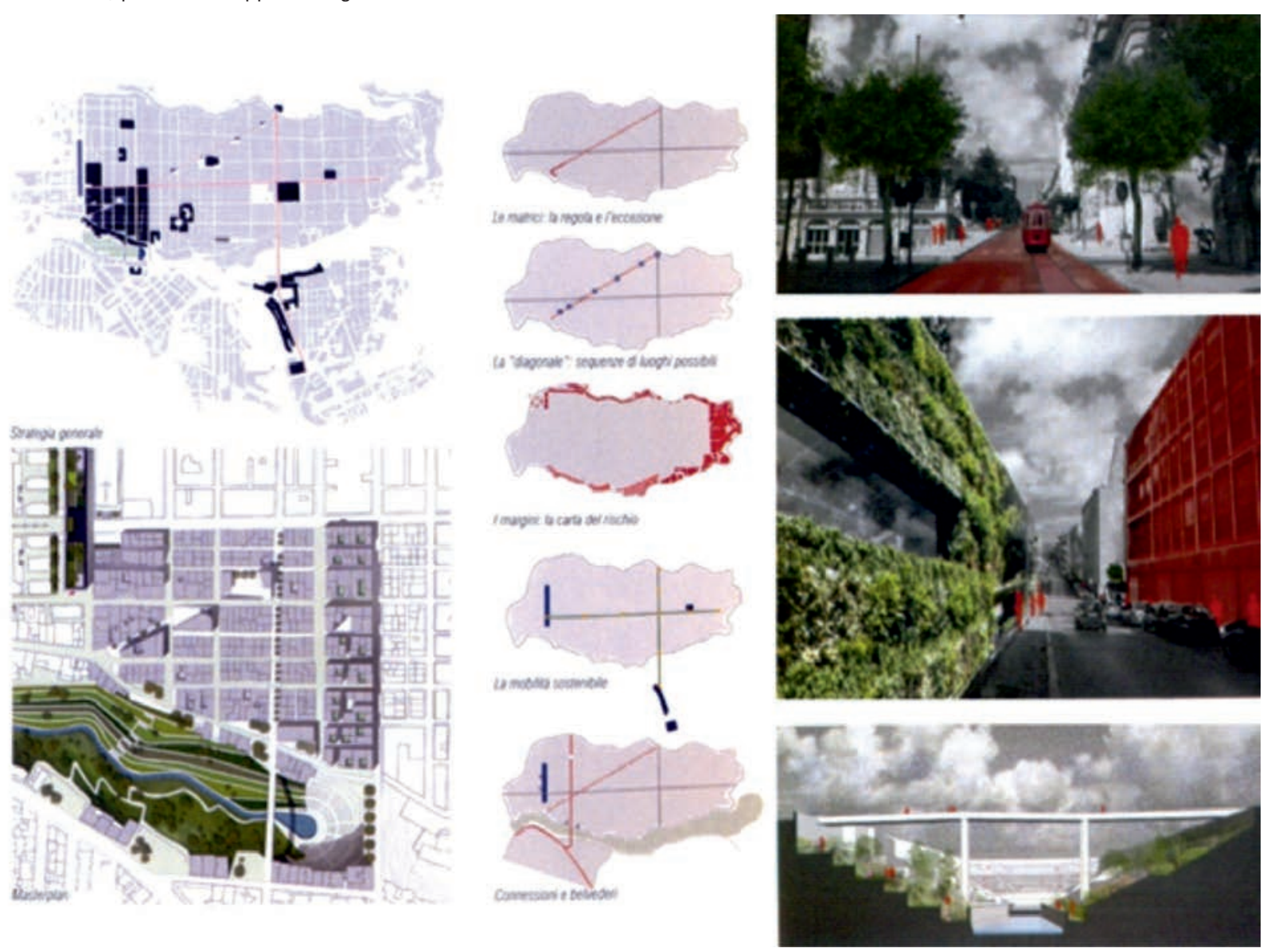

tion with effective actions of others. It changes and ism, with the support of a wider international professional approach.

The effects of this workshop are the fruit of successful, if unusual, cooperation between municipal auprive other, organising this wider highly professional international support.

comicipal authorities, local organisations, and companies got involved in the workshop, recognising its value: the encouragement to search for an appropriate starting point for muncipal management in town of of revitisation of urban centres, the saving of soll and more broally of the environment, and consequently improving the quality of life in historic centres.

Piccitto, the Mayor of Ragusa, and architect Dimartino, the first advocates of the works insepp municipal administration, through architect Marcello Dimartino, head of the territorial sector and of the Historic Centre.

The contribution made by Professor Flaccavento was quite remarkable and remained in the memory of the workshop participants. His 'itinerant narratives' contributed to building a solid bridge between the past and the future of the town, which today constitutes an irreplaceable tool of cultural cohesion for the community of Ragusa.

BIBLIOGRAPHY

1] AA.W. Citta Pubblica/Paesaggi comuni, materiali per il porogetto
degli spazi aperti dei quartieri, ERRP,Roma, Gangemi Editore, 2013 2] AAWV. Costruire nel Costruit::architettura a volume zero, in A

7/2012 A. A. II progetto della città interrotta, Milano, Maggioli Editore. [4] Barbera P., Architettura in Sicilia tra le due guerre, Palermo, Sellerio Editore, 2002 Blanco B., II filo di Arianna ci guida nel Labirinto della città. Strategia erer la riqualificicaione del centro storico di Madrid, in "Milano--Ma-
drid Forma della città e progetto urbano." A cura di Paolo Caputo. drid. Forma della città e progetto urbano." A cura di Paolo Caputo.
Milano, Electa, 1998 [6] Casamento A. Le città ricostruite dopo il terremoto del 1693:tecniFacoltà di Architettura, $20-21$ marzo 1995, Roma, Edizioni Kappa,
7] Di Franco A.CCittà e spazio pubblico, Milano, CLUP, 2005

81 Giovannoni G., II diradamento edilizio nei vecchi centriti i I quartiere
della Rinascenza in Roma, in "Nuova Antologgia", VVIII, n. 997 , luglio 10] Leassi G. Scrititi scelti, 1965-1999, Milano, Franco Angeli Editore, 2000 12] Moneo R., Michele Bonino (a cura di), Costruire nel costruito. Torino, Allemandi, 2007
[13] Nobile M., Ragusa 1928-1938 una città in cantiere: genesi di un capoluogo di Provincia, Ragusa Libreria Paolini Editore, 1994

ero R., Tronchini V., Città e luoghi,Materiali per la citta rimo Scalvedi L., Francesco La Grassa:architettura e urbanistica fraRo-
ma e la Sicilia nella prima metà del novecento, Roma, Librerie Dedalo.
2005 